\title{
An Investigation of the Relation between Pre-service EFL Teachers' Epistemological Cognition and Teaching Approaches
}

\author{
Özkan Kırmız1 ${ }^{\mathrm{a}}$, Aydan Irgatoğlu b,c
}

\begin{abstract}
This study was undertaken to investigate the relation between pre-service EFL teachers' epistemological beliefs and their approaches to teaching. The participants are 105 pre-service EFL teachers, selected based on a random sampling method. To measure pre-service EFL teachers' epistemological beliefs, The Epistemological Beliefs Survey, developed by Chan and Eliott (2004), was used. This survey conceptualizes epistemological beliefs under four dimensions; namely "innate/fixed ability, learning effort/process, authority/expert knowledge, and certainty knowledge." To measure, preservice EFL teachers' approaches to teaching, the Approaches to Teaching Inventory, developed by Trigwell, Prosser, and Ginns (2005), was utilized. This tool has three major subdimensions; "transmission-based, student-teacher interaction, and student focus." Descriptive and correlational statistical analyses were used. The results indicated that pre-service EFL teachers moderately agree with the sub-dimensions of epistemological beliefs and the most important sub-dimension that predict teaching approaches is the effort dimension of epistemological beliefs.
\end{abstract}

Keywords

Epistemological cognition

Teaching approaches

Innate/fixed ability

Pre-service EFL teachers

About Article

Geliş Tarihi: 04.02.2021

Kabul Tarihi: 21.06.2021

Doi: $10.18026 /$ cbayarsos. 874649

\section{İngilizce Öğretmen Adaylarının Epistemolojik Biliş ve Öğretim Yaklaşımları Arasındaki İlişkinin İncelenmesi}

Öz

$\mathrm{Bu}$ çalışma, öğretmen adaylarının epistemolojik inançları ile öğretim yaklaşımları arasındaki ilişkiyi araştırmak amacıyla yapılmıştır. Katılımcılar, rastgele örnekleme yöntemine göre seçilen 105 İngilizce öğretmen adayıdır. EFL öğretmen adaylarının epistemolojik inançlarını ölçmek için Chan ve Eliott (2004) tarafından geliştirilen Epistemolojik İnançlar Anketi kullanılmıştır. Bu araştırma epistemolojik inançları dört boyut altında kavramsallaştırmaktadır; (1) doğuştan / sabit yetenek, (2) öğrenme çabası / süreci, (3) otorite / uzman bilgisi ve (4) kesinlik bilgisi. EFL öğretmen adaylarının öğretim yaklaşımlarını ölçmek için Trigwell, Prosser ve Ginns (2005) tarafından geliştirilen Öğretme Yaklaşımları Envanteri kullanılmıştır. Bu aracın üç ana alt boyutu vardır; (1) aktarım temelli, (2) öğrenci-öğretmen etkileşimi ve (3) öğrenci odaklı. Tanımlayıcı ve ilişkisel istatistiksel analizler kullanıldı. Sonuçlar, öğretmen adaylarının epistemolojik inançların alt boyutlarını orta düzeyde katıldıklarını ve öğretim yaklaşımlarını yordayan en önemli alt boyutun epistemolojik inançların çaba boyutu olduğunu göstermiştir.
Anahtar Kelimeler

Epistemolojik biliş

Öğretim yaklaşımları

Doğuştan / sabit yetenek İngilizce öğretmen adayları

Makale Hakkında

Received: 04.02.2021

Accepted: 21.06.2021

Doi: 10.18026/cbayarsos. 874649

\footnotetext{
a Assoc. Prof, Karabük University, Faculty of Letters, English Language and Literature Department, Karabük, ozkankirmizi@karabuk.edu.tr, https://orcid.org/0000-0003-3419-8257

b Dr. Faculty Member, Ankara Hacı Bayram Veli University, School of Foreign Languages, Ankara, aydan.irgatoglu@hbv.edu.tr, https://orcid.org/0000-0002$0773-4619$

c Correspondent Author: aydan.irgatoglu@hbv.edu.tr
} 


\section{Introduction}

Teachers should always seek to improve their teaching approaches. Teaching approaches and epistemological convictions could even affect teaching. In this study, it is aimed to examine the correlation between teaching approaches and the epistemological beliefs of future teachers. In terms both of revealing insights on the educational process and offering an opinion on approaches to teaching that they can use in the future, it is important to examine teaching approaches. Because of the significance of the ties between philosophy and education in recent years, studies focusing on topics of learning have been increasing and epistemology has become a part of primary concepts in recent years. (Kaleci \& Yazıc1, 2012).

Epistemology is claimed to be a discipline that examines, investigates, and explores the existence, source, limitations, accuracy, reliability, and validity of knowledge and ways to acquire and transmit this knowledge. With this content, epistemology helps to establish points of view on the meaning, creation, and knowledge gathering, while at the same time allowing the individuals to test their points of view. Owing to perceptions and encounters, people have permanent opinions and convictions about knowledge and acquisition of it. These ideas and values influence the epistemological beliefs of a person. It has been argued that epistemological beliefs go beyond beliefs regarding knowledge, as they also cover beliefs regarding learning and learning abilities in the processes of knowledge acquisition and use, which all can be seen as a belief system. People may differ from each other in their beliefs in the dimensions of epistemological beliefs. E.g., while someone thinks that knowledge has a basic and fixed structure, on the other hand, he/she may believe it has a very complex structure that includes numerous ideas (Ekinci, 2017)

Epistemic cognition is the capacity to construct, evaluate, and use knowledge by drawing on determining what is known concerning what is believed, doubted or distrusted. It is also the "capacity to use knowledge" (Greene \& Yu, 2016). It's just what people do if they are committed to knowledge and reality. In this case, teachers have their own epistemological beliefs and may influence their student's epistemological perception (Fives et al., 2017; Buehl, 2008). Barnes et al. (2020) stated teachers need to be aware of the aspects of this information to be successful in facilitating the process of creating knowledge for the students.

Everybody has developed an epistemological conception either consciously or unconsciously. This concept leads a person to establish a global view, continuous beliefs about the process of acquisition of information and knowledge. For both teachers and students, this also appears to apply. Some studies show that the characteristics of epistemological beliefs and teaching behaviors are linked in the literature. There is a connection between student epistemological beliefs and learning materials (Kızılgüneş et al., 2009); that student reasoning is more advanced and therefore has greater problem-solving capacity concerning information and learning (Aksan \& Sözer, 2007). In a study carried out by Kardash \& Howell (2000) with students studying at universities, it was found out that students who think that learning takes place over time, depending on the effort they are putting into researching education materials, make use of the more cognitive techniques that they use (Ekinci, 2017). Moreover, epistemological beliefs of the students were revealed as having a positive relationship with higher-level thought, whether directly or indirectly, with academic achievement, self-efficacy, self-regulation, critical thought \& metacognition attitudes towards schools and preferred learning approaches (Taşkın, 2012). 
Teaching approaches tend to be highly critical. Teaching approaches can be categorized into three major headings as a teacher-centered (based on teacher transmission), a student-centered approach, and a teacher-student interaction approach (Tang et al., 2017). The key focus of the teacher-centered approach focused on the teaching material, time, and conditions. This ensures that teachers are in charge of what is to be learned. The teacher can use various techniques to provide content such as lecture or memorization (Kikas et al., 2016). The second approach, which focuses on students, involves student participation, and encourages students in the learning process. This approach is based on the premise that students are individuals who need guidance for physical, social, emotional, and intellectual development. It depends on whether the experiences of the students are appreciated. Finally, student-teacher interaction mediates the other two. The three methods are reportedly allocated qualitatively along a teacher-oriented and learner-oriented spectrum. Evidence has shown that teachers can take many even opposing teaching approaches (Greene \& Yu, 2016).

Chan \& Elliott (2004) claim that the teachers' preferred teaching approaches reflect their beliefs about the way they learn and teach and that these beliefs include the significance given to the position of teachers and students. The reason why epistemological beliefs in learning are important is that beliefs are regarded as factors that guide actions (Karhan, 2007). The values and value systems of teachers influence their teaching strategy and success by influencing their teaching methods and principles in class (Cheng et al., 2009). This research study conceptualizes epistemological beliefs in four dimensions: innate/fixed skills; learning process; authority knowledge; and certainty knowledge suggested by Chan \& Elliot (2004).

It is argued that the teaching approaches of teachers have evolved from conventional teaching and learning concepts based on knowledge transfer in the concept of education design and implementation to a constructivist interpretation, highlighting knowledge transition. These two principles of teaching vary in their interpretations of the source of knowledge, the essence of learning, and the role of teacher and student. Constructivist learning strategies involve students in the process of understanding or creating information (Brovnlee et al., 2005).

It is proposed that the convergence of psychological and sociological theories having a decisive role in an educational organization has a tendency focused on epistemological expectations (Şengül-Turgut, 2007). It is noted that the building blocks of both the construction techniques and behavioral interventions focused on the issue of knowledge that made them different. The constructivist epistemology does not focus on the intense acquisition of knowledge, but the student's successful reconstruction of it. In this process, cognition is an adaptation mechanism used within a particular context to make the actions of the person more objectionable. It organizes the perceptions of the individuals and constructs meaning on them (Tezci \& Uysal, 2004). The influence of the academic context of teachers is very essential through their epistemological and scientific convictions on achievement. The responses of the students and how they learn can contribute to the formation of environments. The student's method of using resources, and his function in the classroom are important components in this context.

To sum up, based on constructivist philosophy, the constructionist approach emphasizes constructing teaching environments. Such contexts foster critical thinking, exploration, and collaboration. In such an atmosphere, students can discover the habits of solving real-life issues, participating in group works, writing a document or novel, developing models, investigating requests to find answers to research concerns. Besides, the creation of software programs offered special opportunities for the critical thinking skills of students, and research 
has shown that these variables have some impact on their achievement; but the teacher's epistemological belief is the primary determinant of the quality of the teachers (Howard et al., 2000). Thus, it can be argued that since the teacher's epistemological conviction, which is the key determinant factor involved in the design of learning environments, reveals some thoughts on his/her classroom activities, for students to grow advanced epistemological beliefs, teachers ought to have sophisticated beliefs about the essence and the basis of learning. Şengül-Turgut (2007) points out that, to promote the teaching process, a major reform and observation of epistemological acceptability is needed for the preparation of the education and restructure. This study attempts to assess the connection between teaching approaches and epistemological beliefs.

There are also certain researchers in the literature that have analyzed the connection between teaching approaches and epistemological beliefs based on a statistical model (Wang et al., 2015; Sadi \& Dağyar, 2015). This study discusses, however, the relation between dimensions of EBs and teaching approaches.

To put constructivist teaching practices into force in schools, teachers' quality is considered important. The pre-service teacher education programs are critical in providing these qualifications. To introduce such strategies in classrooms, teachers are expected to graduate after developing a constructivist teaching strategy. Therefore, an analysis of the relationship between epistemological beliefs and teaching approaches may be a substantial contribution to the understanding of the current situation as well as the arrangement of teacher education programs.

It has been noted that teacher education programs are undergoing major amendments to improve quality in education (Kirby et al., 2006). The key goal of these programs is the perception of educational principles and contexts. The transition from teacher-oriented education to student-centered education is one of those goals (Yenice, 2015). The studies conducted on this issue indicate that the teaching approaches of teachers influence the learning approaches of students (Dilekli \& Tezci, 2016; Gibbs \& Coffey, 2004). Students who are educated with student-centered approaches have deep learning insight, while the students educated with traditional approaches have more surface learning insight. Besides, it has been stated that the teaching approaches of teachers influence the learning technique of the students. There exist several types of teaching approaches. Three approaches described by Martin \& Balla (1991) are promoting active learning, facilitating the learning process, and introducing new information. Trigwell et al. (2005) categorized approaches to learning as teacher and student-centered approaches. Gow \& Kember (1993) have also classified teaching approaches as 'learning facilitation' and 'knowledge transmission'. Chan \& Elliott (2004) reveal that educators have two philosophical perspectives of teaching as constructivist and traditional teaching concepts.

The conceptual perception of traditional teaching has developed around the objectivist approach and has been determined by teacher-oriented perception or transmission of knowledge. conventional teaching requires teaching with teacher-centered methods, which is why learners are defined as recipients of passive knowledge. Teachers play a major part in the transmission of information. Learners are knowledge processing artists concerning the constructivist principle that is described as part of the student-centered approach. As a result, in constructivist classes, a teacher is considered as a classroom designer where she encourages learning, facilitates the learning process, and becomes the coach of learning. The constructivist 
theory states that knowledge is shaped by the experiences and beliefs of the learners (Fenstermacher \& Soltis, 2004). That is why teachers are considered as designers of the learning environment in classrooms and enablers of learning. Teachers prepare successful learning tasks for learners (Kim, 2005).

Teachers transmit knowledge to students in the traditional approach. Students are passive while receiving information. Traditional classes are also driven by guidance or simple delivery of knowledge. Students are supposed to accept any knowledge without asking questions. During the learning process, there is little communication between students. Students learn on their basis (Chan \& Elliott, 2004). In the conventional or teacher-centered approach teachers usually presume that learners have the same degree of experience and can retain knowledge in the same.

In the constructivist classes students, on the other hand, act or work together in small groups to communicate with others. The teacher enables the students to systematically develop their meaning regarding prior learning, past experiences, and values. Students learn by doing. Students always have a chance to communicate in constructivist classes. Constructivist teachers are expected to sign learning settings to enable students to draw innovative ideas, make inferences, and draw conclusions by solving problems (Gopnik \& Wellman, 2012).

Teaching-learning approaches include the importance of teaching and thinking about students' and teachers' roles (Chan and Elliott, 2004). The research learners in constructivist classes are to be able to access and process the knowledge actively. With this vision, teachers need to promote collaboration and provide more opportunities for students to take responsibility (Schunk, 2015). By the way, learners with this perspective have several significant benefits, such as resolving problems, developing a positive attitude towards learning or educational achievement (Schunk, 2015). Teachers and learners with this view should better accept modern education philosophies (Ornstein, 2015). Nevertheless, the Teacher is the source of information in conventional or surface teaching approach, and the students are passive recipients of knowledge. Teacher centered approaches are more likely to be set to function within the conventional approach. Additionally, it can be claimed that students with this perception are incapable of overcoming unstructured difficulties, devoting themselves towards learning and academic achievement (Schunk, 2015). Traditional philosophies are adopted by teachers with a traditional teaching approach perspective (Ornstein, 2015). Numerous factors affect teaching approaches. These variables may be correlated with epistemological beliefs, creativity, perceptions of nature, gender (Sadi \& Dağyar, 2015).

Teaching approaches of teachers affect the learning approaches of students (Gibbs \& Coffey, 2004). There are therefore several studies have been conducted to develop and transform the teaching approaches of teachers (Stigler \& Hiebert, 2009; Ganser, 2000). The way teachers teach can be influenced by several factors. Studies found out that various factors as understanding, self-confidence, conviction, and behaviors influence teaching approaches (Fenstermacher \& Soltis, 2004). In his study, Ekinci (2010) points out that educational experiences affect teaching approaches. One of the variables that influence the teaching approaches is the epistemological beliefs.

Epistemological beliefs are one of the variables playing a role in teaching approaches (Aypay, 2011). Epistemology is a philosophical notion that represents the essence of understanding, knowledge, and reasoning. Epistemological beliefs are taken up as a multidimensional 
framework, comprising the dimensions of knowledge, understanding, and learning (Aypay, 2011).

The epistemological beliefs of people may be at various rates of complexity. Some people who have developed epistemological belief tendency think that knowledge does continue to be developed, some of the knowledge might be discovered and only a very limited amount of knowledge is changeless. Those people are always critical and consider effort as the most relevant way to acquire information. However, people of naive belief, claim that a considerable amount of knowledge is certain, a part of knowledge is to be sought, and only a small amount of knowledge could change. These individuals become freer to get influenced by what they experience. They, therefore, promote the view that talent is more critical than effort in the creation of competence (Aypay, 2011). In terms of effort, natural capacity, and some expertise, epistemological beliefs can be investigated (Deryakulu \& Büyüköztürk 2005).

Epistemological beliefs are crucial in the teaching process. They are associated with learning, affect the decision-making process, and have implications for teaching. In some studies, epistemological beliefs are reported to have some effect on learning methods, educational efficacy, intense involvement in the learning process, persistence to challenging activities, comprehension of written literature, and coping with some problems (Kapucu \& Bahçivan, 2015; Aypay, 2011). Students with complex epistemological beliefs are expected to use more professional cognitive data processing approaches, supervise more widely and more accurately at which level they have learned the context, demonstrate higher academic achievement, have more favorable behaviors toward schools, are more dedicated to the education process, and produce more complex and diverse ideas. When the relation between epistemological beliefs and teaching approaches is examined, a deep learning approach or constructivist approach is more preferred to be used by learners with sophisticated beliefs. Moreover, learners with naive epistemological beliefs like the traditional approach (Aypay, 2011). Additionally, epistemological beliefs are also expected to develop when a constructivist approach is applied in class environments (Islickk, 2012).

Epistemic cognition is the "ability to construct, evaluate, and use knowledge" by drawing on one's "dispositions, beliefs, and skills [to] determine what [is] actually known versus what one believes, doubts, or distrusts" (Greene and Yu, 2016; 46). It is about what individuals do when they are engaged in knowledge and truth. In that case, teachers occupy a peculiar place in that they both have their personal epistemological beliefs and are likely to affect their students' epistemological cognition (Fives et al., 2017; Buehl \& Fives, 2016). According to Barnes et al. (2020), for teachers to be effective in fostering students' knowledge construction process, they must be aware of the dimensions of that knowledge.

It is possible to categorize teaching approaches under three main headings: (1) teacher-centred approach (based on the transmission of the subject matter by the teacher), (2) student-centred approach, and (3) student-teacher interaction approach (Kikas et al., 2016; Tang et al., 2017; Trigwell, 2012). The main focus in teacher-centered approach is the content, time and conditions of teaching, which means that teachers are in control of what is to be taught and when and what are the specific conditions of teaching. The teacher may employ different techniques to deliver the content such as lecturing or memorizing (Silinskas et al., 2016).

The second approach, student-centered approach, involves student engagement and assisting students in the process of learning. This approach is based on the idea that students are 
independent individuals and they need guidance to develop physically, psychologically, emotionally, and intellectually. This depends on the realization that students' experiences are valued. Finally, student-teacher interaction, mediates the other two approaches.

As such, the present study aims at investigating the potential correlations between and among the sub-dimensions of epistemological beliefs and teaching approaches. To this end, the following research questions have been formulated:

Research questions:

1. What are pre-service EFL teachers' epistemological beliefs?

2. What are pre-service EFL teachers views regarding teaching approaches?

3. Is there a correlation among sub-dimensions of epistemological beliefs and teaching approaches?

\section{Method}

\section{Participants}

The present study was conducted with 105 pre-service EFL teachers. The number of female participants is 37 and the number of female participants is 68. The number of first grade students is 46,27 of whom are female and 19 are male. The number of second grade students is 30 . Twenty of them are female and 10 of them are male. The number of 3rd grade students is 19. Eleven of them are female and eight of them are male students. The number of 4 th grade students is 10 . There are no male students in the 4 . grade students. Table 1 gives information about the participants.

Table 1. Descriptive Statistics about the Participants

\begin{tabular}{llccc}
\hline & & \multicolumn{2}{c}{ Gender } & Total \\
\cline { 3 - 4 } & & female & male & \\
\cline { 3 - 4 } Grade & 1 grade & 27 & 19 & 46 \\
& 2 grade & 20 & 10 & 30 \\
& 3 grade & 11 & 8 & 19 \\
Total & 4 grade & 10 & 0 & 10 \\
\hline
\end{tabular}

\section{Data Collection Tools and Procedure}

1. Epistemological Beliefs Survey (EBS): This survey was developed by Chan and Eliott (2004). It includes five subscales, which are "Innate/Fixed Ability (8 items), Learning Effort/Process (11 items), Authority/Expert Knowledge (6 items), and Certainty Knowledge (5 items)". The Cronbach's alpha value for the EBS was calculated as ,761, indicating an acceptable level of reliability. The results are presented in Table 2 .

2. The Approach to Teaching Inventory (ATI) was developed by Trigwell, Prosser, and Ginns (2005). It is a 22-item tool including three approaches to describe teaching: "(a) knowledge transmission, (b) student-teacher interaction, and (c) student focus". Knowledge transmission involves the transmitting of knowledge by the teacher. Student-teacher interaction involves teachers' helping students in grasping facts and recognizing associations between them. 
Finally, student focus necessitates bringing the learner to the focus of instruction. ATI is a 5point Likert type scale. The reliability and validity of ATI has been ascertained in different contexts (Trigwell, 2012). The Cronbach's alpha value for ATI was calculated as ,778, indicating an acceptable level of reliability. The results are presented in Table 2.

Table 2. Reliability Analysis

\begin{tabular}{lcc}
\hline Variables & $\begin{array}{l}\text { Number of } \\
\text { items }\end{array}$ & Cronbach's alpha value \\
\hline Epistemological beliefs & $\mathbf{2 6}$ &, $\mathbf{7 6 1}$ \\
Innate & 8 &, 797 \\
Learning effort & 13 &, 644 \\
Authority & 3 &, 531 \\
Certainty knowledge & 6 &, 443 \\
Teaching philosophies & 17 &, 758 \\
Transmission & 7 &, 625 \\
Student-teacher interaction & 5 &, 778 \\
Student focus & 5 &, 660 \\
Total & 47 &, 693 \\
\hline
\end{tabular}

\section{Findings}

In this section, initially the descriptive statistics regarding epistemological beliefs and teaching approaches are presented. Descriptive statistics about epistemological beliefs are presented in Table 3. As we can understand from Table 3, the general mean score for EBs is 3,2125, implying that the participants are undecided about the items here. As for innate knowledge, pre-service EFL teachers seem to disagree with the items in this category $(M=2,4936)$. This shows that preservice EFL teachers do not believe that their abilities are fixed at birth or they are limited to their innate abilities. They also do not seem to agree that some people are born as good learners. These findings indicate that for the pre-service EFL teachers in the present study do not value the innate aspect of knowledge and knowledge acquisition.

With regard to learning effort, the pre-service EFL teachers in the present study seem to have agreed with the items here $(\mathrm{M}=3.8877)$. This shows that the pre-service EFL teachers in the present study partially agree that knowing how to learn is more important, and it is not possible to learn without putting an effort. Moreover, they partially agree that everyone needs to learn how to learn and they need to focus on the process of understanding. Next, the preservice EFL teachers in the present study disagree with the items in authority category $(\mathrm{M}=2.5481)$. They seem to depend on the advice coming from experts and do not believe that knowledge is tentative or uncertain. Finally, when it comes to certainty knowledge, the preservice EFL teachers in the present study are undecided about the items in this category $(\mathrm{M}=3.0404)$. They seem to have doubts about whether scientists will get the truth if they try hard and whether there should be a teaching method that is applicable to all situations. They do not seem to agree that scientific knowledge is certain and fixed.

Table 3. Descriptive Statistics about Epistemological Beliefs Findings 


\begin{tabular}{lccccc}
\hline $\begin{array}{l}\text { Epistemological } \\
\text { beliefs }\end{array}$ & $\mathrm{N}$ & Minimum & Maximum & Mean & Std. Deviation \\
\hline Innate & 105 & 1 & 5 & 2.4936 & 5.11241 \\
Learning effort & 105 & 1 & 5 & 3.8877 & 4.77980 \\
Authority & 105 & 1 & 5 & 2.5481 & 2.03331 \\
Certainty knowledge & 105 & 1 & 5 & 3.0404 & 2,9000 \\
Total & 105 & 1 & 5 & 3.2125 & 6,9961 \\
\hline
\end{tabular}

The descriptive statistics regarding teaching approaches are presented in Table 4 . This table makes it clear that the participants opted more for student-teacher interaction $(\mathrm{M}=3,8877)$ rather than knowledge transmission ( $\mathrm{M}=2.4936)$ or student focus $(\mathrm{M}=2.5481)$. Depending on these results, it can be said that, with regard to knowledge transmission, the pre-service EFL teachers in the present study do not believe that the aim of teaching is not all about formal assessment and do not believe that teaching is only for the sake of providing notes to students. They do not think that teaching is only for good presentation of information to students. In terms of student-teacher interaction, it can be said that the participants agree that teaching helps students develop new ways of thinking and it is vital to monitor how students' understanding changes. Furthermore, the pre-service EFL teachers in the present study partially agree that teaching should enable students to question their own understanding of the subject matter.

Table 4. Descriptive Statistics Regarding Teaching Approaches

\begin{tabular}{lccccc}
\hline Approach to Teaching & $\mathrm{N}$ & Minimum & Maximum & Mean & Std. Deviation \\
\hline Knowledge transmission & 105 & 1 & 5 & 2.4936 & 5.11241 \\
$\begin{array}{l}\text { Student-teacher } \\
\text { interaction }\end{array}$ & 105 & 1 & 5 & 3.8877 & 4.77980 \\
Student focus & 105 & 1 & 5 & 2.5481 & 2.03331 \\
\hline
\end{tabular}

\section{Gender Differences}

In order to see whether there are any gender differences in terms of the sub-dimensions of EBs and teaching approaches, we conducted a T-test. The results are presented in Table 5. We can understand from the table that there are gender differences in terms of two points. The first is about knowing how to learn $(\mathrm{p}=, 038, \mathrm{p}<0,005)$. Male pre-service EFL teachers believe that learning how to learn is more important than fact acquisition. The next difference is that female pre-service EFL teachers believe that there is a definite answer to every problem $(p=, 008$, $\mathrm{p}<0,005)$.

Table 5. Gender Differences in EBS and Teaching Approaches.

\begin{tabular}{llllrr}
\hline \multicolumn{1}{c}{ Items } & gender & $\mathrm{f}$ & $\mathrm{m}$ & $\mathrm{t}$ & sig. \\
\hline Knowing how to learn is more & female & 65 & 4,1324 & $-2,107$ &, 038 \\
$\begin{array}{l}\text { important than the acquired facts } \\
\text { (effort) }\end{array}$ & male & 36 & 4,4444 & & \\
& female & 65 & 2,1324 & 2,709 &, 008 \\
\hline
\end{tabular}




\begin{tabular}{llll}
\hline There is a definite answer to every & male & 36 & 1,7222
\end{tabular}

problem (authority)

\section{Grade Level Differences}

In order to see whether or not there are grade level differences in terms of EBs and teaching approaches, Kruskall Wallis test was conducted. The reason why we conducted Kruskal Wallis is that the number of the participants are not normally distributed and the number of 4th grade students is rather low. The results are presented in Table 6. Table 6 indicates that there are grade level differences in terms of whether teaching should be a way of helping students find their ways in learning sources. Secondly, first and second grade students differ in terms of whether they would provide students chances to discuss their understanding (p. , $021<0.05)$.

Table 6. Grade Level Differences

\begin{tabular}{llllllc}
\hline item & $\begin{array}{l}\text { grade } \\
\text { level }\end{array}$ & $\mathrm{n}$ & mean & $\mathrm{F}$ & Sig. & Dif. \\
\hline 10. Teaching should include helping & 1 grade & 46 & 4,5000 & 6,923 &, 000 & $1-2$ \\
students find their own learning resources & 2 grade & 29 & 4,0345 & & & $1-3$ \\
& 3 grade & 18 & 3,8333 & & & $1-4$ \\
& 4 grade & 10 & 3,8000 & & & \\
& 1 grade & 46 & 4,3696 & 3,389 &, 021 & $1-2$ \\
16. I would make available opportunities & 2 grade & 30 & 3,9000 & & & \\
for students to discuss their changing & 3 grade & 18 & 4,2222 & & & \\
understanding. & 4 grade & 10 & 4,3000 & & & \\
& & & &
\end{tabular}

\section{Correlation between Epistemic Beliefs and Teaching Approaches}

In order to see the correlation between EBs and teaching approaches, correlation analysis was conducted. The results are presented in Table 7. As we can understand from Table 7, there is a moderate level of positive correlation between epistemological beliefs and teaching approaches $(\mathrm{r}=.-269, \mathrm{p}<.01)$.

Table 7. The Correlation between Epistemic Beliefs and Teaching Approaches

\begin{tabular}{llr}
\hline \multicolumn{1}{c}{ Epistemic } & Teaching approaches \\
\hline Epistemic & 1 &, $269^{*}$ \\
Teaching approaches & & 1 \\
$*$. Correlation is significant at the 0.05 level (2-tailed). &
\end{tabular}

Table 8 presents the results of correlation analysis pertaining to the sub-dimensions of EBs and teaching approaches. The findings show that the innate dimension does not correlate with any of the teaching approaches. However, significant positive correlations were observed between the effort dimension and the teaching approaches. For example, a high level of correlation was observed between effort and student-focus $(\mathrm{r}=.469, \mathrm{p}<.01)$. The effort dimension also correlated with student-teacher interaction $(\mathrm{r}=.398, \mathrm{p}<.01)$. 
Table 8. The Correlation between Subdimensions of Epistemic Beliefs and Teaching

\begin{tabular}{|c|c|c|c|c|c|c|c|}
\hline \multicolumn{8}{|c|}{ Approaches } \\
\hline & innate & effort & authority & certainty & transmission & $\begin{array}{c}\text { student- } \\
\text { focus }\end{array}$ & $\begin{array}{l}\text { student- } \\
\text { teacher }\end{array}$ \\
\hline innate & 1 &,$- 355^{* *}$ & ,048 &,- 146 &,- 107 &,- 055 &,- 150 \\
\hline effort & & 1 &,- 002 & $278^{* *}$ & 181 & $469^{* * *}$ & $398^{* *}$ \\
\hline authority & & & 1 & 137 & 133 &,- 061 &,- 096 \\
\hline certainty & & & & 1 &,- 014 &,- 015 & ,019 \\
\hline transmission & & & & & 1 & ,203* & ,209" \\
\hline student-focus & & & & & & 1 & $485^{*+}$ \\
\hline student- & & & & & & & \\
\hline teacher & & & & & & & 1 \\
\hline
\end{tabular}

Finally, multiple regression analysis was conducted to determine whether pre-service EFL teachers are predicted by EBs. The results of the analysis of variance related to regression analysis are shown in Table 9. Table 9 indicates that the model established for the prediction of teaching approaches and EBs is meaningful $(\mathrm{F}(7,806)=29,754 ; \mathrm{p} .000)$.

Table 9. The Results of Analysis of Variance Related to Prediction of Teaching Approaches

\begin{tabular}{lccccc}
\hline Model & Sum of Squares & df & Mean Square & F & Sig. \\
\hline Regression & 929,055 & 4 & 232,264 & 7,806 &, 000 \\
Residual & 2499,304 & 84 & 29,754 & & \\
Total & 3428,360 & 88 & & & \\
\hline
\end{tabular}

Table 10 presents the results of the regression analysis on EBs and teaching approaches. According to the results, the only factor that predicts teaching approaches is effort $(\beta=.554)$. The other sub-dimensions of EBs were not found to predict teaching approaches.

Table 10. The Results of Regression Analysis on EBS and Teaching Approaches

\begin{tabular}{lrrrrr}
\hline & \multicolumn{1}{c}{ B } & Std. Error & \multicolumn{1}{c}{ Beta } & \multicolumn{1}{c}{ Sig. } \\
\hline (Constant) & 33,088 & 8,340 & & 3,968 &, 000 \\
innate &, 062 &, 126 &, 050 &, 493 &, 623 \\
effort &, 716 &, 132 &, 554 & 5,414 &, 000 \\
authority &,- 071 &, 280 &,- 024 &,- 254 &, 800 \\
certainty &,- 216 &, 211 &,- 102 & $-1,026$ &, 308 \\
$\mathrm{R}=, 521 ; \mathrm{R} 2=, 271 ;$ & & & & & \\
\hline
\end{tabular}

\section{Discussion}

The present study was designed to see the role of EBs on teaching approaches on the part of pre-service EFL teachers. Findings indicated that pre-service EFL teachers have a moderate level of EBs. This shows that pre-service EFL teachers do not assume that our abilities are fixed at birth or we are limited to our innate abilities, nor do they agree that some people are born good learners. The pre-service EFL teachers in the present study partially agree that knowing 
how to learn is more important, and it is not possible to learn without putting effort. What is more, the pre-service EFL teachers provided partial support to the idea that everyone needs to learn how to learn.

The second aim of the study was to see pre-service EFL teachers' beliefs as to teaching approaches. The findings indicated that pre-service EFL teachers gave a moderate level of support to knowledge transmission and student focus. The approach that received the most attention from pre-service EFL teachers was student-teacher interaction. This demonstrates that one of the most important aims of teaching should be to help students find new ways of thinking. They also reported that students' progress should be observed by teachers.

As for the variance analysis, some gender and grade level differences were observed. First of all, gender differences were seen in two items. Male pre-service EFL teachers believe that learning how to learn is more important that fact acquisition. The next difference is that female pre-service EFL teachers believe that there is a definite answer to every problem. As for grade level differences, it was seen that while 1. grade students believe that teaching should enable students to find their way in learning resources 3. and 4. grade students seem to be undecided about this item. Such a move is not something desirable and does not indicate a sophistication in EBs.

The next aim of the study was to see the correlation between EBs and teaching approaches. A rather low level of positive correlation was observed between EBs and teaching approaches. The innate dimension did not correlate with any of the teaching approaches. However, significant positive correlations were observed between the effort dimension and the teaching approaches. For example, a high level of correlation was observed between effort and studentfocus. The effort dimension also correlated with student-teacher interaction. Finally, the regression analysis indicated that the only sub-dimension of EBs that predicted teaching approaches was effort dimension. This means that pre-service EFL teachers value the effort for learning.

The present study did not find a high level of sophistication in terms of EBs. However, there are some important points as to them. First of all, teacher education programs ought to be aware of the factors that enable pre-service teachers to form EBs. The second point that requires attention is that, as was suggested by Greene \& Yu (2016), teachers' EBs must be supported for both pre-service and in-service teachers. For pre-service teachers, courses like epistemology, the philosophy of science, etc can be added to the program. And in-service teachers can be supported through in-service training programs. This is called epistemically informed praxis by Fives et al. (2007).

Another important point as to EBs is that they are subject to change through instruction (Kienhues et al., 2008; Sosu and Gray, 2012; Tanase \& Wang, 2010). In particular, Sosu and Gray (2012) indicated in their study that pre-service EFL teachers' beliefs about ability, sources of knowledge, certainty knowledge and learning process can be changed through instruction provide that alternative instructional techniques are presented to them.

\section{Conclusion}

The present study was designed to see whether there are potential relations between and among the dimensions of EBs and teaching approaches. The starting point for the study was the consideration that EBs may play a role in determining pre-service EFL teachers' emerging beliefs and approaches to teaching. The results showed that pre-service EFL teachers do not 
have very high EBs and they tend to opt for a rather student-teacher interaction model. And, the dimension that predict pre-service EFL teachers' teaching approaches was the effort dimension of EBs.

Depending on these results, it can be claimed that the pre-service EFL teachers do not yet have developed a clear understanding of constructivism, the prominent approach in education today. Therefore, teacher education programs should pay more strict attention to the implementation of constructivism in language education. In a similar vein, epistemic cognitions are also highly important as they play a significant role in determining teachers' actions. Moreover, epistemological beliefs are also expected to develop when a constructivist approach is applied in class environments (Islicik, 2012). Therefore, teacher education programs should also integrate epistemological beliefs. To do this, courses like epistemology, the philosophy of science, etc can be added to teacher education programs.

There are limitations to the study. In the first place, the present study is based on survey method. Although valuable insights have been drawn from the results, it would also be a better idea to integrate qualitative data to the study. Therefore, future studies can be based on mixed-methods research. A second point that merits attention in terms of EBs is that they are changeable over time. Hence, future longitudinal studies can also be designed to measure how they change over time or whether teacher education programs have an influence on them or not.

\section{Ethics Committee Approval Information}

This research was conducted considering ethical issues and in accordance with ethical rules. Ethics Committee Approval Certificate Dated 02.12.2020 and numbered 11054618-302.08.01 was obtained from Ankara Hacı Bayram Veli University Ethics Committee.

\section{References}

Aksan, N., \& Sözer, M. A. (2007). Universite ögrencilerinin epistemolojik inançları ile problem çözme becerileri arasındaki ilişsiler. Ahi Evran Uñiversitesi Kırşehir Egitim Fakultesi Dergisi (KEFAD), 8(1), 31- 50.

Aypay, A. (2011). Epistemolojik inançlar ölçeğinin Türkiye uyarlaması ve öğretmen adaylarının epistemolojik inançlarının incelenmesi. Eskişehir Osmangazi Üniversitesi Sosyal Bilimler Dergisi, 12(1); 1-15.

Barnes, N., Fives, H., Mabrouk-Hattab, S., \& SaizdeLaMora, K., (2020). Teachers' epistemic cognition in situ: evidence from classroom assessment, Contemporary Educational Psychology.

Brownlee, J. M., Thorpe, K. J., \& Stacey, P. S. (2005). Improving learning and teaching in early childhood teacher education: A focus on personal epistemology. Retrieved from http://eprints.qut.edu.au/2126/1/2126.pdf. 11.01.2021.

Buehl, M. M. (2008). Assessing the multidimensionality of students' epistemic beliefs across diverse cultures. In M.S. Khine (Ed.), Knowing, Knowledge and Beliefs (pp.65-112). Dordrecht, Springer. 
Chan, K. W., \& Elliott, R. G. (2004). Relational analysis of personal epistemology and conceptions about teaching and learning. Teaching and Teacher Education, 20(8), 817-831.

Cheng, M. M., Chan, K. W., Tang, S. Y., \& Cheng, A. Y. (2009). Pre-service teacher education students' epistemological beliefs and their conceptions of teaching. Teaching and Teacher Education, 25(2), 319-327.

Deryakulu, D., \& Büyuiköztürk, S, (2005). Epistemolojik inanc, ölçeginin faktör yapısının yeniden incelenmesi: Cinsiyet ve ögrenim görulen program türüne göre epistemolojik inançların karşılaștırılması. Eğ̈tim Araş,tımaları, 18: 57-70.

Dilekli, Y. \& Tezci, E. (2016). The relationship among teachers' classroom practices for teaching thinking skills, teachers' self-efficacy towards teaching thinking skills and teachers' teaching styles. Thinking Skills and Creativity, 21, 144-151.

Ekinci, N. (2010). Universite ögrencilerinin ögrenme yaklaşımları. Egĭtim ve Bilim, 34(151), 7488.

Ekinci, N. (2017). Examining the Relationships between Epistemological Beliefs and Teaching and Learning Conceptions of Lower-Secondary Education Teachers, Inonu University Journal of the Faculty of Education, 18(1), 344-358. DOI: 10.17679/inuefd.307065

Fenstermacher, G. D. \& Soltis, J. F. (2004). Approaches to Teaching. Amsterdam Avenue, New York, NY: Teachers College press.

Fives, H., Barnes, N., Buehl, M. M., Mascadri, J., \& Ziegler, N. (2017). Teachers' epistemic cognition in classroom assessment. Educational Psychologist, 52(4), 1-14.

Ganser, T. (2000). An ambitious vision of professional development for teachers. NASSP Bulletin, 84(618), 6-12.

Gibbs, G. \& Coffey, M. (2004). The impact of training of university teachers on their teaching skills, their approach to teaching and the approach to learning of their students. Active Learning in Higher Education, 5(1), 87-100.

Gopnik, A. \& Wellman, H. M. (2012). Reconstructing constructivism: Causal models, Bayesian learning mechanisms, and the theory. Psychological Bulletin, 138(6), 1085-1108.

Gow, L. \& Kember, D. (1993). Conceptions of teaching and their relationship to student learning. British Journal of Educational Psychology, 63(1), 20-23.

Greene, J. A., \& Yu, S. B. (2016). Educating critical thinkers: The role of epistemic cognition. Policy Insights from the Behavioral and Brain Sciences, 3(1), 45-53.

Howard, B. C., McGee, S., Schwartz, N., \& Purcell, S. (2000). The experience of constructivism: Transforming teacher epistemology. Journal of Research on Computing in Education, 32(4), 455-465.

Islıcık, T. (2012). Yapılandırmacı Ö̈r̆enme Ortamlarının Bilimsel Epistemolojik Inançlara Etkisi. Fen Bilgisi Eğitimi Bilim Dalı. Gazi Universitesi, Ankara.

Kaleci, F. \& Yazıc1, E. (2012). Epistemolojik inançlar üzerine bir derleme. 10. Ulusal Fen Bilimleri ve Matematik Egitimi Kongresi. Niğde Universitesi. 
Kapucu, S. ., \& Bahçivan, E. . (2015). High school students"e scientific epistemological beliefs, self-efficacy in learning physics and attitudes toward physics: a structural equation model. Research in Science and Technological Education, 33(2), 252-267.

Kardash, C. M. \& Howell, K. L. (2000). Effects of epistemological beliefs and topic-specific beliefs on undergraduates' cognitive and strategic processing of dual-positional text. Journal of Educational Psychology, 9(3), 524-535.

Karhan, I. (2007). Ilkö̈retim okullarında gö̈ev yapan ögretmenlerin epistemolojik inançlarmın demografik özelliklerine ve bilgi teknolojilerini kullanma durumlarma gö̈e incelenmesi. Doctoral dissertation, Yıldız Teknik University, Istanbul, Turkey.

Kizilgünes, B., Tekkaya, C., \& Sungur, S. (2009). Modeling the relations among students' epistemological beliefs, motivation, learning approach, and achievement. The Journal of Educational Research, 102(4), 243-256.

Kienhues, D., Bromme, R., \& Stahl, E. (2008). Changing epistemological beliefs: The unexpected impact of a short-term intervention. British Journal of Educational Psychology, 78, 545-565

Kikas, E., Silinskas, G., Jogi, A. L., \& Soodla, P. (2016). Effects of teacher's individualized support on children's reading skills and interest in classrooms with different teaching styles. Learning and Individual Differences, 49, 270-277.

Kim, J. S. (2005). The effects of a constructivist teaching approach on student academic achievement, self-concept, and learning strategies. Asia Pacific Educ. Rev. 6(1), 7-19.

Kirby, S. N., McCombs, J. S., Barney, H. \& Naftel, S. (2006). Reforming Teacher Education: Something Old, Something New. Arlington, V A: Rand Corporation.

Martin, E. \& Balla, M. (1991). Conceptions of teaching and implications for learning. Research and Development in Higher Education, 13, 298-304.

Ornstein, A. C. (2015). Philosophy as a Basis for Curriculum Decisions. In A. C. Ornstein, E. F. Pajak, \& S. B. Ornstein (Eds.), Contemporary Issues in Curriculum (6th ed., pp. 2-9). Boston: Pearson.

Sadi, O:, \& Dagyar, M. (2015). High school students ee epistemological beliefs, conceptions of learning, and self- efficacy for learning biology: A study of their structural models. Eurasia Journal of Mathematics, Science and Technology Education, 11(5), 1061-1079.

Schunk, D. H. (2015). Learning Theories: An Educational Perspective. Pearson Education.

Sosu, E.M. \& Gray, D.S. (2012). Investigating change in epistemic beliefs: An evaluation of the impact of student teachers' beliefs on instructional preference and teaching competence, International Journal of Educational Research, 53, 80-92.

Stigler, J. W. \& Hiebert, J. (2009). The Teaching Gap: Best Ideas from The World's Teachers for Improving Education in The Classroom. NY: Simon and Schuster.

Ș,enguil-Turgut, G. (2007). Yapılandırmacı yaklaşıma dayalı öğretimin lise fizik öğrencilerinin epistemolojik inanışlarına etkisi. Master's thesis, Marmara University, Istanbul, Turkey.

Tanase, M., \& Wang, J. (2010). Initial epistemological beliefs transformation in one teacher education classroom: Case study of four preservice teachers. Teaching and Teacher Education, 26, 1238-1248. 
Tang, X., Kikas, E., Pakarinen, E., Lerkkanen, M., Muotka, J., \& Nurmi, J. (2017). Profiles of teaching practices and reading skills at the first and third grade in Finland and Estonia. Teaching and Teacher Education, 64, 150-161.

Taşkın, C. S. (2012). Epistemolojik inançlar: Oğretmen adaylarının ögrenme yaklaşımlarını yordayıc bir degissken. Mustafa Kemal Universitesi Sosyal Bilimler Enstitü̈ü Dergisi, 9(19), 273-285.

Tezci, E., \& Uysal, A. (2004). Eğitim teknolojisinin geliş̧imine epistemolojik yaklașmların etkisi. The Turkish Online Journal of Educational Technology (TOJET), 3(2), 158-164.

Trigwell, K., Prosser, M., \& Ginns, P. (2005). Phenomenographic pedagogy and a revised Approaches to Teaching Inventory. Higher Education Research and Development, 24(4):349360

Trigwell, K. (2012). Relations between teachers' emotions in teaching and their approaches to teaching in higher education. Instructional Science, 40, 607-621. https://doi.org/10.1007/s11251-011-9192-3

Wang, Y., Tsai, C., \& Wei, S. (2015). The Sources of Science Teaching Self-efficacy among Elementary School Teachers: A mediational model approach. International Journal of Science Education, 37(14), 2264- 2283.

Yenice, N. (2015). An analysis of science student teachers' epistemological beliefs and metacognitive perceptions about the nature of science. Educational Sciences: Theory $\mathcal{E}$ Practice, 6, 1623-1636. 